\title{
Expanded Maternal and New Born Survival Program on Strengthening Mother and Child Health Referral System in Cilacap, Indonesia
}

\author{
Indah Sulistyoningrum ${ }^{1)}$, Uki Retno Budihastuti²), Endang Sutisna ${ }^{1)}$ \\ 1)Masters Program of Public Health, SebelasMaret University, Surakarta \\ 2) Department of Obstetrics and Ginecology, Dr. Moewardi Hospital, Surakarta \\ 3)Faculty f Medicine, Sebelas Maret University, Surakarta
}

\begin{abstract}
Background: In 2012, the maternal mortality rate or MMR and infant mortality rate or IMR in Cilacap, Central Java, tends to increase through the Expanding Maternal and Neonatal Survival or EMAS. This study aimed to determine the implementation expanding maternal and new born survival program in strengthening mother and child health and referral services.

Subjects and Method: This was qualitative study. This was conducted in Cilacap.A total of 16 health professional and four societies. The informants were team leader of EMAS, EMAS quality improvement coordinator, civil society coordinator strengthener of EMAS, head of health service in Cilacap, and Chairman of the Civil Society Forum. The data was collected with interviews, observation and document and analyzed using content analysis.

Results: The results of this study showed that the standard policy of the implementation of the EMAS clear, precise, clear measurable was indicators of achievement. Objectives of this study could be understood by health professionals and civil society of maternal and child health forum. Health professionals resources in an amount sufficient, with the competence and there was lack equipment and drugs in health centers. Networking system of EMAS utilization was optimal in public health center and hospitals. Communication is effective starting from the initial visit, counseling, socialization, and comparative study. Characteristics of executing agencies indicate good working procedures. Disposition implementer showed a positive attitude and support. The environmental conditions of social, political and economic support. Some of the program started in Cilacap to reduce MMR and IMR and fairly produced significant results.

Conclusions: It is suggested to Cilacaphealth service to hold aid and medicine midwife training to improve skills in handling emergency cases of maternal and neonatal.
\end{abstract}

Keywords: Expanding Maternal and New Born Survival, maternal mortality, infant mortality

\section{Correspondence:}

Indah Sulistyoningrum. Masters Program in Public Health, Sebelas Maret University, Jl. Ir. Sutami 36 A, Surakarta 57126, Central Java.

\section{BACKGROUND}

Cilacap Health Office data in 2012, maternal mortality rateis increasing, became 34 cases or 111.2/100.000 live births with a cause that is bleeding (27\%), eclampsia (23\%), and post natalinfection (50\%). Cilacap Regency infant mortality rate increases in 2012 were 11.5/1,000 live births. As many 7.8/1,00o infant mortality caused in neonatal period. (Cilacap District Health Profile, 2014).
Department of Health in cooperation with USAID to lowering maternal mortality rate and infant mortality rate in 2012 through an Expanding Maternal and Neonatal Survival (EMAS) program. The lowering maternal mortality rate and infant mortality rate by $25 \%$ in 30 counties in 6 provinces, one of which is the County of Cilacap (a national network of training clinics, 2008). 
The preliminary results of the study show that there are many changes both in terms of services and also governance, including Standard Operating procedures (SOP) in terms of reference system, record keeping and reporting as well as standard services.

\section{SUBJECTS AND METHOD}

This was a qualitative study with case design. A total of composed of health care personnel in 2 clinics PONED, 2 hospitals PONEK, determining policy, and society. Primary data obtained by means of indepth interviews, observation and study of documents, while the secondary data obtained from clinics, hospitals and Health Service Administration Cilacap, namely in the form of a report which supports the Research Program.

$\frac{\text { RESULTS }}{\text { 1. Standard policy }}$

The results obtained during that interview guidelines for implementing a Program of EMAS based on user's Guide technical implementation activities and the performance monitor tool in the form of the clinic as well as a reference. Guidelines in addition to the technical guide and monitor performance, such as Circulars from DKK containing about rules EMAS Program implementation or success indicator is relied upon to carry out a Program of EMASdoes not exist. The following statements of informants: "need once the existence of the guidelines, the fact that the guidelines given in the form of soft copy, because it was of EMAS we can know how we will be in increase of its spatial layout, skillnya way of referring" (women, midwives, coordinator of the child).

Based on the results of the review document, the guidelines that exist cur- rently only contains technical guide the implementation of the program of EMAS.The existence of guidelines on implementation as noted above are justified by District Team Leader (DTL) EMAS, and head of the UPT Clinic the following commentary:

"Guides the implementation of the program of EMAS based on the Ministry of health, so the guidelines from the Ministry of health in the US, and the same layout that is in a SOP clinics, job aid, books, video training". Barriers related to the EMAS program modules, namely the number of modules that owned only 1 , so not all midwives have it.

\section{Policy objectives}

The entire health workforce informer says EMAS Program aims to improve the quality of service so that it can lower the battery and infant mortality rate, thus can be explained that the actual purpose of the midwife program implemented familiar EMAS and was supported also by the existence of technical implementation guide as well as monitor performance of good clinical as well as a system of reference. Following her:

Although in the document or the current guidelines are not listed the purpose of the Pogram in EMAS, but with the knowledge that in the pass at the time of training, as well as the sophistication of science and technology, health care personnel can see and know the purpose of the implementation of the programme of EMAS from different sources.

\section{Resources}

Head Space VK IGD "We formed a team of emergency, red green yellow red team, he reported everything to him later in the yellow team to instruct to carry out then Green team as a complement to complete implementation of the materials it e.g. vacum soon" (female,). 
Besides the observation made in the VK IGD, when patients with critical conditions, which are properties when it is already dividing the tasks according to the position in the team, so it's not all midwives when it handles a patient, but some are setting up equipment, contact a doctor Sp. Og and some were documented.

Need for a special competence that owned by midwives, especially the skills in handling emergenciesin support of performance. It is also supported by the DTL EMASCilacap that need for competence in terms of handling emergencies, where health workers must be skilled in performing actions which can be trained through emergency drills (simulation).

A midwife at home ill apply well, where sijariemas with the reference system by using sijariemas, hopefully no more "hospital" tour and all the references communicated in advance as well as patients are already getting stabilization prior to referral.

$\frac{\text { DISCUSSION }}{\text { 1. Standards policy }}$

Research results showed the existence of a written policy standard yet in an official document/manual program execution. The absence of this will make multiinterpretation in the implementation of the program. According to Subarsono (2012) every public policy must have standards and policy objectives are clear and measurable, that can be reached all its objectives.

It is also in accordance with the theory of implementation according to Van Meter and Van Horn that every public policy must have standards and a clear policy objectives and measurable, that can be reached all its objectives (Soebandono, 2012).

\section{Policy objectives}

Results of the study showed all the informants know EMAS program objectives namely lowering maternal mortality and infant mortality. According to Subarsono (201) every public policy must have clear policy objectives and measurable, that can be reached all its objectives. Otherwise public policy goals with the obscure will cause multi-interpretation and easily give rise to misunderstanding and conflicts among the executor implementation. Midwives need to know clearly about the standards and the policy objectives because of the vagueness of the standards and the policy objectives is one of the factors that make not maximized midwives in the discharge of the implementation of the program.

This is in line with the research of Ruspita (2013) that understanding the clerk about the size of the base and the purpose of the policy is a very important thing in the execution of a program. The existence of standards and policy objectives can help to evaluate and make the next step.

\section{Resources}

This study showed that health workers are now more skilled in the handling of the case of emergency. This competency improvement gained from training and emergency drills are carried out routinely. But program implementation proved insufficient due to the equipment and medication that is not yet complete.

According to Agustino (2008) that in the implementation of the policy needs to support resources, both human resources (human resources) as well as material resources (matrial resources) and the resource methods (method resources), the third of such resources, the most important are the human resources, as well as the subject of the implementation of the policy also includes the object of public policy.

It is supported by Muslim (2011) that facilities should be available in quantity as well as the adequate type and always ready 
to use so that the implementation of a behavior. This is supported by research Muslimah (2011) that are seen in terms of the quality of a midwife who is trained and not trained to be different in terms of granting of services and perform services where midwives who have been trained are likely to follow standard operational procedures.

Sijariemas is already exploited to the maximum by the hospital and health center. According to Carwoto (2013) that sijariemas proved to be able to prevent the occurrence of rejection of the request reference by all hospitals, increasing the readiness of the hospital to receive a referral, as well as reduce delay in the handling of reference in network services reference maternal and neonatal emergencies. Information systems are implemented can also be a useful database for the sake of decision maternal mortality ratein the hospital or health service.

\section{Communication}

Research results showed in the execution of the program, communication is done through various means, among others, teamwork change every 3 months, training, reporting a routine 3 months once, supervision, evaluation and mentoring. According to Subarsono (2012) communication and coordination is one of the veins of an organization so that programs can be realized is appropriate goals and objectives.

Sharif mentioned that supervision has the purposeto motivate officers and control an activity to fit a predetermined standard. Such activities in order to discover irregularities and straighten If found irregularities so as to provide excitement and feedback to officers implementing (Syamsurizal, 2007).

Implementation will run effectively in support of communication and coordination, if information sources give inconsis- tent interpretation then the implementers will face difficulty to execute it. Good communication can be used as a motivation and can push the feeling to participate and be more interesting attention to jobs (Agustino, 2008).

\section{The implementing Agency Charac- teristics}

The research results showed that the record-keeping and reporting after the EMAS program is certainly more orderly and more complete. The reporting should be made when it's already focused in 1 book register in which will be:

1. Implementation EMAS program policy clear, precise policy goals, the goals of clear and measurable, there are indicators of achievement.

2. The purpose of well understood by health workers and the public

3. Resources in the amount of enough health workers, health workforce competency with the good, there is still a lack of drugs and equipment in clinics and hospitals, community participation in the form of mentoring in high risk pregnant women with maternal mortality rate.

4. Effective communication ranging from early visits, mentoring, socialization, and study the appeal. The implementing agency characteristics show the good work procedures.

5. Attitude/disposition shows the positive attitude of the implementers that support the program.

6. Environmental conditions social, political and economic support, range of area, health workers, communities, and some religious organizations.

\begin{tabular}{r}
\hline REFERENCE \\
\hline Armstrong C, Magoma M, Ronsmans C \\
(2015). Magnitude of maternal and \\
neonatal mortality in Tanzania: A sys- \\
tematic review. International Journal
\end{tabular}


of Gynecology and Obstetrics. 130:98 -110 .

Bhandari (2012).Effect of implementation of Integrated Management of Neonatal and Childhood Illness (IMNCI) programme on neonatal and infant mortality. BMJ: 344 .

Budi W (2008). Kebijakanpublik, teoridan proses. Yogyakarta: Medpress.

Carwoto W, Bambang (2015). Pengembangan dan Implementasi SistemInformasi Jejarring Rujukan Kegawatdaruratan Maternal Neonatal Berbasis Web dan Sms (Short Message Service). http://download.portalgaruda.org. Diakses 17 Oktober 2015.

Depkes (2015). Upaya PercepatanPenurunan Angka Kematian Ibu dan Bayi Baru Lahir di Indonesia. http://www.gizikia. depkes.go.id. Diakses 22 Desember 2015 .

(2012). Upaya Percepatan Penurunan Angka Kematian Ibu dan Bayi Baru Lahir di Indonesia. http://www.gizikia.depkes.go.id. Diakses tanggal 26 November 2015.

Dinas Kesehatan Kabupaten Cilacap (2012). Prosedur Penatalaksanaan Informasi dan Komunikasi Rujukan Gawat Darurat Melalui Sistem Informasi dan Komunikasi Jejaring Rujukan Maternal dan Neonatal (SIJARIEMAS) Kabupaten Cilacap. (2012). Profil Kesehatan 2011. (2013). Profil Kesehatan 2012. (2014). Profil Kesehatan 2013.

Dirjen Bina Gizi dan KIA (2012).Expanding Maternal Neonatal Survival.

English M (2003). Causes and outcome of young infant admissions to a Kenyan district hospital. US National Lib Rari Of Medicine National Institutes of Health. 88:438-443.

George T (2008). Prinsip-prinsip Manajemen. Jakarta: PT.BumiAksara.
Haver J, Brieger, Zoungrana J, Ansari N, Kagoma J (2015). Experiences engaging community health workers to provide maternal and newborn health services: Implementation of four programs. International Journal of Gynecology and Obstetrics. 130:S32-S39.

Hulton L,Matthews Z, Hilber A, Adanu R (2014). Using evidence to drive action: A "revolution in accountability" to implement quality care for better maternal and newborn health in Africa. International Journal of Gynecology and Obstetrics. 127: 96-101.

Horwood C (2009). The Training Experience and Implementing IMCI In South Afrika. http://www.biomedcentral.com. Diakses 4 April 2016.

Kemenkes RI (2013). RencanaAksiPercepatanPenurunanAngkaKematianIbu di Indonesia. http://www.gizikia.depkes.go.id. Diakses tanggal 26 November 2015.

Kemenkes RI (2014). Bidan Berperan Penting Turunkan maternal mortality rate dan infant mortality rate. Artikel Kesehatan. http://buk.depkes.go.id. Diakses 25 November 2015.

(2013). Situasi Kesehatan Ibu. www.depkes.go.id. Diakses 7 Februari 2016.

(2013). RencanaAksi Percepatan Penurunan Angka Kematian Ibu di Indonesia. www.depkes.go.id. Diakses tanggal 7 Februari 2016

(2014). Jadilah Kartini Indonesia yang Tidak Mati Muda (Pencanangan Kampanye Peduli Kesehatan Ibu 2014). Http://www.depkes.go.id. Diakses 7 Februari 2016.

Kemenpppa. Angka Kematian Ibu Melahirkan Maternal Mortality Rate. http://kemenpppa.go.id. Diaksestanggal 25 November 2015. 
Kirana (2013). Kematian Maternal. http://repository.usu.ac.id. Diakses pada 25 November 2015.

Lal A, Gao W, Hibbard J (2013). Eclampsia: Maternal and neonatal outcomes. International Journal of Women's Cardiovascular Health. 3:186-190.

Manuck T, Rice M, BailitJ, Grobman W, Reddy U, Wapner R (2015). Preterm neonatal morbidity and mortality by gestational age: a contemporary cohort. American Journal of Obstetrics and Gynecology.

Miller P,Rashida G, Tasneem Z, Haque M (2012). The effect of traditional birth attendant training on maternal and neonatal care.International Journal of Gynecology and Obstetrics. 117:148152.

Moseson H, Massaquoi M, Bawo L, Birch L, Dahn B, Zolia Y (2014). Estimation of maternal and neonatal mortality at the subnational level in Liberia.International Journal of Gynecology and Obstetrics. 127: 194-200.

Murti B (2013). Desain dan Ukuran Sampel Untuk Penelitian Kuantitatif dan Kualitatifdi Bidang Kesehatan. Yogyakarta: GadjahMada University Press.

Muslimah (2013).AnalisisPerbedaan KinerjaBidanDesa yang Sudah dan Belum Dilatih Manajemen Terpadu Bayi Muda dalam Penatalaksanaan Kunjungan Neonatal di Kabupaten Kudus Tahun 2011. Semarang: Fakultas Kesehatan Masyarakat. UNDIP.

Mutomima N (2014). Implentasi Program Peningkatan Kelangsungan Hidup Ibu dan Bayi Sebagai Upaya untuk Meningkatkan Kualitas Kesehatan (Studi tentang Program EMAS di Dinas Kesehatan Kabupaten Sidoarjo), 2(7). Prabamurti P, Purnami C, Widagdo L, Setyono S (2008). Analisis Faktor Risiko
Status Kematian Neonatal. Studi Kasus Kontrol di Kecamatan Losari Kabupaten Brebes. Jurnal Promosi Kesehatan Indonesia.3 (1).

Sanusi R (2013). Meningkatkan Program EMAS. https://rossisanusi.wordpress.com. Diakses 17 Oktober 2015.

Saputra W, Fanggidae V, Mafthuchan A (2013). Efektivitas Kebijakan Daerah dalam Penurunan Angka Kematian Ibu dan Bayi. Jurnal Kesehatan Masyarakat Nasional.7(12).

Seim A, Alassoum Z, Bronzan R, Mainassara A (2014). Pilot community-mobilization program reduces maternal and perinatal mortality and prevents obstetric fistula in Niger. International Journal of Gynecology and Obstetrics. 127:269-274.

Sinaga M (2007). BeberapaFaktorSosial Demografi Yang Berhubungan Dengan Tingginya Angka Kematian Ibu di Propinsi Nusa Tenggara Timur. https://mediakesehatanmasyarakat.files.wordpress.com. Diakses tanggal 7 Februari 2016.

Sugiartik F (2014). Pelaksanaan Program Emas (Expanding Maternal And Neonatal Survival) PuskesmasKabupaten Malang (StudiKasus Di Puskesmas Permata Turen). http://eprints. uns. ac.id. Diakses17 Oktober 2015.

Sulaeman E (2015). Metode Penelitian Kualitatif dan Campuran Dalam Kesehatan Masyarakat. Surakarta: UNS PRESS.

Sulaeman E (2010). Reorganisasi dan Revitalisasi Program Keterpaduan KB Kesehatan (Posyandu) di Era Desentralisasi. http://fk.uns.ac.id. Diakses tanggal 7 Februari 2016.

Suryana C (2010).Data danJenis Data Penelitian. 